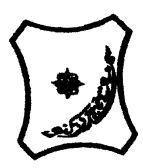

Bayero Journal of Pure and Applied Sciences, 10(1): 285 - 288

Received: April, 2017

Accepted: May, 2017

ISSN $2006-6996$

\title{
PROXIMATE ANALYSIS OF SELECTED SORGHUM CULTIVARS
}

\author{
Jimoh, W.L.O. ${ }^{1}$ and Abdullahi, M.S. ${ }^{2}$ \\ Department of Pure and Industrial Chemistry, Bayero University, Kano \\ National Biotechnology Development Agency, Abuja
}

\section{ABSTRACT}

Two sorghum samples yellow and white cultivated in three different local Government areas of kano (Viz:Tsakuwa (Dawakin Kudu), Burum - Burum (Tudun Wada), Kibiya) and four hybrid Sorghum samples from Institute of Agricultural Research A.B.U Zaria were analyzed for proximate composition. The results revealed that protein content ranged from $6.23-13.81 \%$, carbohydrate $65.57-76.28 \%$, lipid $3.60-10.54$, fibre $1.65-7.94 \%$, ash $1.12-1.68 \%$, and moisture $9.75-$ $16.32 \%$. The proximate analysis revealed that sorghum samples contains appreciable nutrient contents. Also from the result, it has shown that the values of the improved varieties from the Institute for Agricultural research (IAR) Zaria is higher in the parameters analysed as compared to the local samples. The mineral composition of the sample studied showed highest distrbution pattern of Fe $\left(Y K, 31.95 \mu g g^{-1}\right), C u\left(Y T, 7.27 \mu g g^{-1}\right), Z n\left(S_{40} 59.81 \mu g g^{-1}\right), M g\left(Y K .110 .74 \mu g g^{-1}\right) \mathrm{Ca}$ $\left(Y T, 40.85 \mu g g^{-1}\right), C u\left(S_{17}, 8.0 \mu g g^{-1}\right), C d\left(S_{14}, 0.99 \mu g g^{-1}\right)$, and $P b$ was only detected in white sorghum of Burum -Burum variety $\left(0, .64 \mu g g^{-1}\right)$.

Keywords : Cultivars, Proximate analysis, Sorghum, Composition, Minerals.

\section{INTRODUCTION}

sorghum (Sorghum bicolor) is an important food crop particularly in arid and semi arid tropics. It is a dual purpose crop providing staple food for human consumption (35\%) and the rest as a fodder for livestock, alcohol production as well as preparation of industrial products (Awika and Rooney,2004). Many people in Africa and Asia depend on sorghum as the stuff of life. Being a drought tolerant crop, it can give dependable and stable yield in both raining and post raining seasons. It thrives with less rainfall than is needed for rice and maize and can be grown where no other major cereal can be cultivated. Altogether, sorghum is one of the several really indispensable crops required for the survival of man. According to FAO (1995) report, sorghum was grown globally on an area of about 46 million ha with a production of about 60 million tons. However in India, sorghum is cultivated on an area of about 9.10 million ha with a production of about 7.65 million tons (Anonymous 2006a, 2006b).

The role of plants in the maintenance of good health is well known. These plants constitute an enormous reservoir of wide variety of compounds, which exhibit some medicinal and nutritive properties(Edeoga and Gomina, 2003).

Sorghum food material is readily available in Nigeria and has promising nutritional attribute. Whole sorghum grain is an important source of B-complex vitamins and some minerals like phosphorous magnesium, calcium, and iron (FAO, 1995). The protein content of sorghum is similar to that of wheat and maize, with lysine as the most limiting amino acid (FAO, 1995).

Sorghum, guinea corn or great millet (sorghum bicolor) is the world third important food grain being exceeded in utilization for food by wheat and rice. It is the chief grain food in much of Africa, Asia and South America. In Nigeria, sorghum is also known as guinea corn. The composition of sorghum grain is similar to maize in many respects. Typical analytical figures for the grain are starch $68-80 \%$, protein 10 $15 \%$, moisture $11-12 \%$, fat $3 \%$, fibre $2 \%$, ash $2 \%$ food energy 394 calories. It ranks second to maize in total available energy among the cereal grains (Ihekoronye, 1985).

Nutritionally, sorghum has high carbohydrate content in form of starch. The protein content is significant and comparable to that of wheat and maize but its digestion is an obstacle to its nutritive value. It has a high fat content than wheat or rice, but, it is lower than that of maize. Some varieties of sorghum have high dietary fibre content. Unfortunately this tends to have adverse effect on the availability of some nutrients. Sorghum is also known to be a rich source of B-complex ( $\beta$-carotene), but its quantity also varies with the environment in which the sorghum was grown (Ihekoronye, 1985).

Proximate analysis is the most common analysis done for nutrient testing. Proximate testing includes fats, proteins, moisture, fibre, ash and carbohydrate . Each of the proximate test has testing varations that are applied to specific food types (Simpkin and William, 1990s).

An element is essential when it is consistently determine to be present in all healthy living tissues and when its deficiency symptoms are noted, with depletion or removal, which disappears when the elements are provided to the tissues (Olivares and Uauy, 1996). 
Of the essential metals, iron, copper and zinc are well known for their biochemical role in the human body. Iron is an essential metal in the biochemical system, i.e. hemoglobin in blood, which is the most important iron complex consisting of the globin protein with four heme units attached to it. Likewise, copper is found in enzymes capable of carrying oxygen as hemoglobin does, and it is actually required in the formation of this substance. Zinc, another essential element is approximately100 times as abundant as copper in the human body. It has the ability to occupy low symmetry sites in enzymes(Corn, 1993).

As far as non-essential elements are concerned, chromium is known to cause lung cancer. Lead accumulation results first in reduced functioning of kidney, liver and brain cells and later in complete breakdown of the tissue. Cadmium and its compounds are also toxic to humans. They produce acute and chronic symptoms varying in intensity from irritation to extensive metabolic disturbance (Mueller and Anke, 1994).

Minerals are large family of nutrients essential to the human body, although some of them are present in the body in very small amounts, probably several part per million. They are designated as essential trace elements because most of them are the core elements of thousands of enzymes displaying various functions or acting as catalysts, for certain enzymes. They are also components of hormones and certain factors with special physiological function (Ingaski, 2005)

\section{OBJECTIVES}

To compare the nutritional value of the improved sorghum (from IAR, Zaria) with the local varieties.

To assess the suitability of some of the local varieties for further improvement. To find the level of some metals present in the Sorghum

\section{MATERIALS AND METHODS}

All the containers, glass wares used were cleaned thoroughly with detergent,

rinsed in tap water and finally distilled water. Analar grade regents were used throughout the analysis.

Six different samples were collected from Kibiya, Tsakuwa and Burum-Burum in Kano State, two samples from each sampling areas and four improved samples from institute of Agricultural Research, Zaria. The samples were sorted, cleaned and ground separately using pestle and mortar to a powder form; they were stored in plastic containers for analysis.

\section{Proximate Analysis}

Proximate analysis of food is the determination of the major components of food which includes moisture, lipids (fats), ash (mineral), protein, carbohydrate and fibre. These methods are however not in any way perfect but act as guide for empherical estimations.

Procedures recommended by (AOAC, 1984) that is Association of Official Analytical Chemist, were used for the analyses.

\section{RESULTS AND DISCUSSION}

Table 1 shows the results of the proximate analysis of the samples investigated.
The result of the moisture content for local varieties ranged between $9.75 \%$ - $16.32 \%$ with a mean of $13.49 \%$ and standard deviation of $3.67 \%$ that agrees with the literature value reported by Ihekoronye, (1985). Mustapha and Magdi (2003) reported 8.33\%$8.58 \%$ and $\mathrm{Abu}$, (2001) reported $1.20 \%-1.92 \%$ for moisture content which are in agreement with the improved value of 1.39 - 7.21 moisture content with a mean of $3.13 \%$ and standard deviation of 2.74 . The ash content is an indication of mineral content of a sample. Ash content of a sample cultured in 3 different locations were found in the ranged 1.12 $1.68 \%$ with a mean of $1.67 \%$ and standard deviation of $0.36 \%$.The sample (improved) shows a range of $1.51 \%-1.64 \%$ with a mean of $1.53 \%$ and standard deviation of $0.20 \%$. The ash content of the sample may be affected by the nature and amount of ion present on the soil from which plants draw their food (Akinsola, 1993). Mustapha and Magdi (2003) reported the ash content of $1.90 \%-1.97 \%$ which is higher than the result obtained in this study but Abu (2001) reported ash content of $1.01 \%-1.56 \%$ which agrees with the result obtained in this work.

The local sample gives a high value of lipid content ranging from $9.08 \%-10.54 \%$ with a mean of $9.78 \%$ and standard deviation of $0.60 \%$ which is similar to Asha et al.,(2005) with a lipid content of $16.10 \%$; while the improved sample recorded low lipid content ranging from $3.60 \%-5.33 \%$ with a mean of $4.71 \%$ and standard deviation $0.80 \%$ which is in agreement with the value reported by other reasearch works of Torres et al., (2006) 2.76\% - 3.75\%; Mustapha and Magdi (2003) 3.58\% - 4.47\%; Abu, (2001) 2.22\% $3.65 \%$. The low level of lipid in improved sample attest to the suitability of the sample for baking in terms of good keeping quality while sufficient enough to participate in the formulation of dough structure (Martin et al,1991). High rate of nitrogen fertilizer were reported to reduce seed oil content in India (FAO, 1994). Fat are more concentrated energy food than carbohydrates. The energy value of fat 9 kilo calories per gram compare to 4 kilo calories per gram of carbohydrates (Okanlawon, 2000)

The results of the protein content obtained for local sample ranged between $6.56 \%-8.02 \%$ with a mean of $7.10 \%$ and standard deviation of $0.32 \%$ while the improved sample protein content ranged between $10.91 \%-13.81 \%$ with a mean of $11.99 \%$ and standard deviation of $1.28 \%$ which is in accord with the works of Torres et al., (2006) of 9.01\% -11.43\%; Asha et al.,(2005) of $10.40 \%$ and Abu, (2001) of $10.08 \%-15.55 \%$ protein contents. The variations in protein content of the various samples are primarily due to the nature and deficiency of essential element required for plant life (Arnon, 1995).

The quality of a protein is determined by the varieties of the amino acid which it contains and which in consequence it can give to the body (Arnon, 1995) protein of vegetable origin, however does not in general, provides all the necessary amino acid and hence it has limited biological value and it is referred to as second class (Mc Donald et al, 1995) 10-20\% protein content required for good baking properties (Olugbemi, 1993). 
The mean crude fibre content of the local sample is $2.79 \%$ with standard deviation of $0.60 \%$ and range value $1.65 \%-3.34 \%$ while the improved sample ranged $3.42 \%-8.13 \%$ with a mean value of $5.09 \%$ standard deviation of $2.29 \%$. This value compare favorably with the works of Mustapha and Magdi (2003) that ranged from $1.64 \%-2.66 \%$; Asha et al.,(2005) of $1.21 \%$ and Abu et al.,(2001) $1.04 \%$ $2.81 \%$ crude fibre contents.Abu et al., (2001) reported carbohydrates value of $81.32 \%$ - $82.7 \%$, Mustapha and Magdi (2003) reported a range value of $68.81 \%-69.65 \%$ carbohydrate content. This is in agreement with the ranged value of the local sample of $66.63 \%-77.25 \%$, a mean of $71.83 \%$, standard deviation $3.45 \%$ and improved sample range of $69.69 \%-77.0 \%$ and mean value of $72.77 \%$, standard deviation of $3.53 \%$.

Table 1:Proximate Composition (\%) of Sample Analysed*

\begin{tabular}{|c|c|c|c|c|c|c|}
\hline Sample & Moisture & Ash & Lipid & Crude protein & Carbohydrate & Crude fibre \\
\hline WT & $9.75 \pm 1.66$ & $1.32 \pm 0.09$ & $9.40 \pm 0.90$ & $6.56 \pm 1.09$ & $74.52 \pm 1.15$ & $2.76 \pm 0.81$ \\
\hline $\begin{array}{l}\text { YT } \\
\text { WK }\end{array}$ & $\begin{array}{l}14.14 \pm 0.83 \\
10.42 \pm 0.10\end{array}$ & $\begin{array}{l}1.68 \pm 0.08 \\
1.33 \pm 0.15\end{array}$ & $\begin{array}{l}10.42 \pm 0.55 \\
10.54 \pm 0.19\end{array}$ & $\begin{array}{l}6.89 \pm 1.01 \\
6.23 \pm 1.09\end{array}$ & $\begin{array}{l}67.16 \pm 1.07 \\
71.24 \pm 1.42\end{array}$ & $\begin{array}{l}2.90 \pm 0.50 \\
2.90 \pm 0.01\end{array}$ \\
\hline YK & $19.02 \pm 2.21$ & $1.46 \pm 0.06$ & $9.08 \pm 1.27$ & $7.30 \pm 0.63$ & $65.15 \pm 2.75$ & $1.65 \pm 0.43$ \\
\hline WB & $11.30 \pm 0.30$ & $1.12 \pm 0.06$ & $9.39 \pm 1.34$ & $8.02 \pm 0.63$ & $70.85 \pm 1.06$ & $3.34 \pm 0.51$ \\
\hline YB & $16.32 \pm 0.13$ & $1.44 \pm 0.03$ & $9.87 \pm 0.43$ & $7.62 \pm 0.63$ & $65.57 \pm 0.91$ & $2.79 \pm 0.03$ \\
\hline S14 & $1.39 \pm 0.05$ & $1.51 \pm 0.46$ & $5.33 \pm 0.20$ & $11.35 \pm 1.38$ & $68.71 \pm 3.80$ & $3.42 \pm 4.42$ \\
\hline S41 & $1.95 \pm 0.20$ & $1.61 \pm 0.41$ & $3.60 \pm 0.67$ & $11.90 \pm 0.02$ & $75.67 \pm 4.83$ & $6.84 \pm 2.87$ \\
\hline $\begin{array}{l}\text { S40 } \\
\text { S17 }\end{array}$ & $\begin{array}{l}1.94 \pm 0.27 \\
7.21 \pm 0.99\end{array}$ & $\begin{array}{l}1.64 \pm 0.34 \\
1.57 \pm 0.42\end{array}$ & $\begin{array}{l}4.79 \pm 0.72 \\
5.12 \pm 0.52\end{array}$ & $\begin{array}{l}13.81 \pm 1.89 \\
10.91 \pm 1.31\end{array}$ & $\begin{array}{l}73.29 \pm 5.13 \\
76.28 \pm 2.15\end{array}$ & $\begin{array}{l}7.94 \pm 3.81 \\
4.85 \pm 2.27\end{array}$ \\
\hline
\end{tabular}

*Values are means \pm S.D of triplicate determinations.

KEY:

$\begin{array}{ccc}\text { YB } & \text { YELLOW } & \text { B/BURUM } \\ \text { WT } & \text { WHITE } & \text { TSAKUWA } \\ \text { YT } & \text { YELLOW } & \text { TSAKUWA } \\ \text { WK } & \text { WHITE } & \text { KIBIYA } \\ \text { YK } & \text { YELLOW } & \text { KIBIYA } \\ \text { WB } & \text { WHITE } & \text { B/BURUM }\end{array}$

Table2:Mineral and Trace elements Concentration of the Samples Analysed $\left(\mathrm{Ugg}^{-1}\right)$

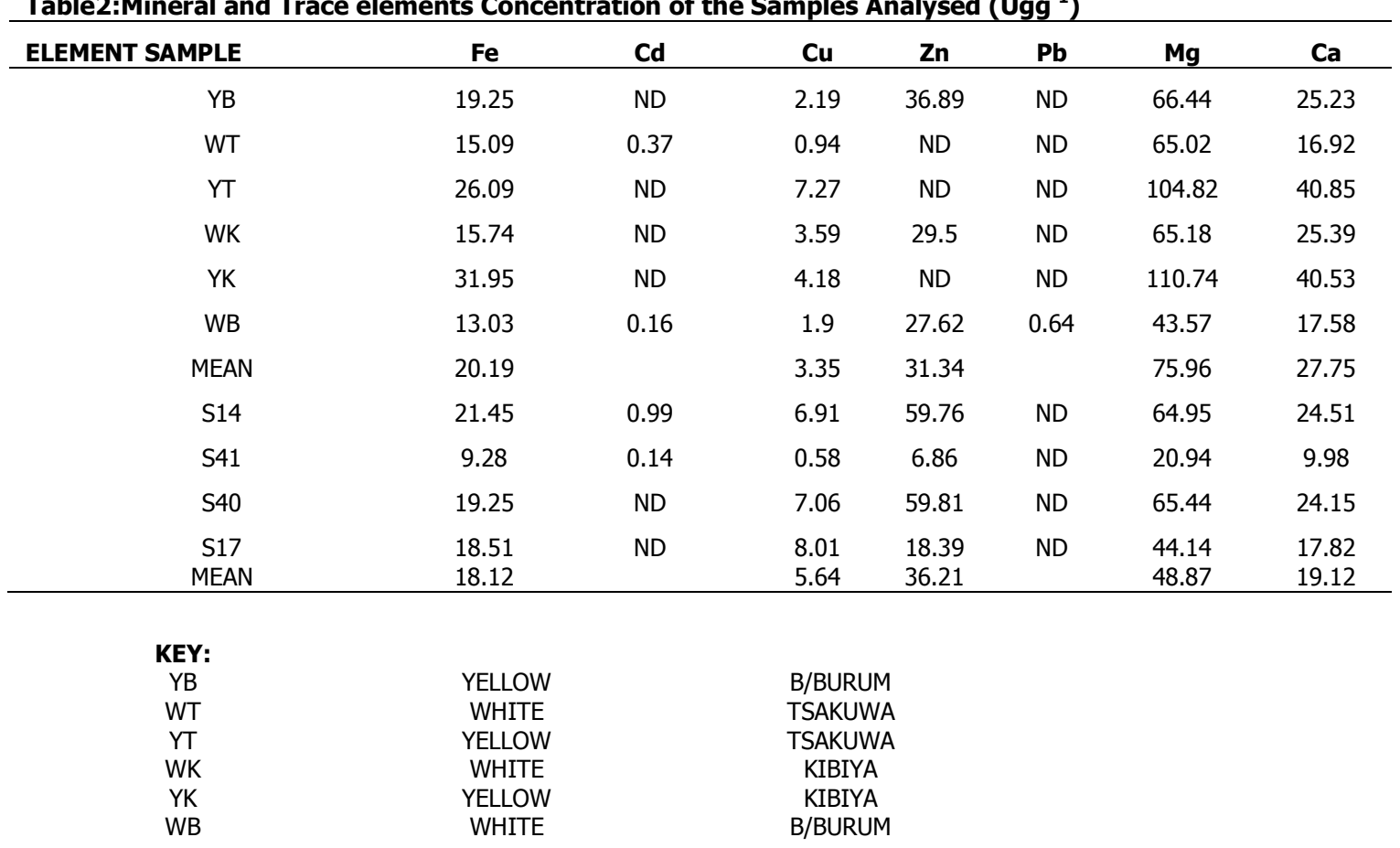




\section{CONCLUSION}

The proximate analysis revealed that sorghum samples contains appreciable nutrient contents. It has shown that, the values of the improved varieties from the Institute for Agricultural research (IAR) Zaria is higher in the parameters analysed as compared to the local sample.

\section{REFERENCES}

Abu, A.E, Aba, D.A, Chindo, P.S, Ango, K.M and Maigida, D.N (2001). Biochemical evaluation of ten sorghum cultivars compared with Wheat for baking characteristics. Institute of Agricultural Research, Zaria.

Akinsola,R.O.,(1993). Nutritional value of some poultry feeds in Nigeria, Msc Dissertation, Bayero University,Kano.Pp 12-35.

Anonymous (2006a). Rabi sorghum research report presented in Research Review committee Meeting, Mahatma Phule Krishi Vidyapeeth, Rahuri p1-182.

Anonymous (2006b).Reports on trials nurseries kharif,rabi and forage sorghum presented in: $36^{\text {th }}$ Annual Group Meeting held at marathwada Agricultural University,Parbhani,11-13 may 2006 vol.,2:pp209

AOAC (1984). Official Method of Analysis of the Association of the Analytical Chemists, $14^{\text {th }}$ Edidition Washington, DC ., USA Pp 152-16 2 .

Arnon,D.I.,(1995). Criteria of essentiality of inorganic micro-nutrients for plants with special reference to molybdenum in trace elements in plant physiology, Chronica Botanical Company, Waltham mass. Pp 120.

Asha, V.B, Geetha, K., Sheela, K., and Nanapal, G.N (2005). Nutritional composition of Sorghum and Moth Bean. Incorporated Traditional Recipes. Journal of Human Ecology 17 (3): Pp 201-203

Awika, J .M and L.W Rooney (2004) Sorghum Phytochemicals and their Potential Aspect on Human Health, Photochemistry 65: 1999 1221

Corn, M.(1993). Handbook of Harzadous Materials, Academic Press, San Diego, CA Pp 772.

Edeoga, H. O. And Gomina, A. (2003). Nutritional values of some Non-conventional Leafy Vegetables of Nigeria. J. Eco. Taxon Bot. 24: 7-13

F. A. O. (1995). Sorghum and Millets in Human Nutrition. Food and Nutrition Series FAO Rome Italy Pp 49-86.

F.A.O (1997). Human Nutrition in Developing World. F.A.O Food and Nutrition Series No. 29. Food and Agricultural Organization of United Nations, Rome.

\section{Recommendations}

Since sorghum grain is staple food, further improvement in grain yield should be attempted to get dual-purpose crop giving high yields of grains and stem biomass.

Protein energy malnutrition can be tackled more efficiently and successfully by incorporating underutilized cereal which are equally nutritious like any other traditional cereal.

Ihekoronye, A.I and Ngoddy, P.O, (1985) . Integrated Food Science and Technology for Tropics. MacMillan Education Ltd. London.

Ingaski, M.A (2005) Proximate Analysis of Cassia Sieme, Msc dissertation (unpublished) Department of Chemistry, Usman Danfodio University, Sokoto.

Mcdonald, P, Edward, R.A, Greenhart, F.D and Morgan, C.A (1995). Animal Nutrition Prentice-hall, London Pp 101-122

Mueller, M. and Anke, M. (1994). Distribution of Cadmium in the Food Chain (soil-planthuman), of a Cadmium Expose Area and the Health Risks of the General Population, Sci. Total Environ. 156,151-8.

Mustapha, A.A.G, and Magdi, A.O (2003). Proximate Composition and Content of Sugars, Amino Acids, and Anti Nutritional Factors of three Sorghum varieties. Agricultural research centre, King Sa'ud University, Pp 5-19

Okanlawon,O.E.,(2000). Post-harvest Handling of Grains. Nigeria Stored Product Research Institute, kano. Pp12.

Olivares, M. And Uauy, R.(1996). Limits of Metbolic Tolerance to Copper Biological Basis for Present Recommendation and Regulation, Am. J. Clin. Nutr. 63, 846s-52s.

Olugbemi, L. B.,(1993). Current Status and Prospects of Composite Flour Technology with particular References to Sorghum for Bread and Biscuits. Paper presented at the Regional Symposium on current progress in the processing and utilization of Sorghum and other Related Cereals Ouagadougou. 22-26 th Nov.,1993.

Simpkins, I. and Williams, J. I. (1990). The Mammalian Alimentary System, Advanced Biology. $3^{\text {rd }}$ edition.ELBS, London Pp 278-280.

Torres Cepeda, T.E, Alanis Guzman, M.G and Maiti, R. (2006). Relation between Nutritional Composition and Anatomical Parameter in Sorghum Retrieve, vol. 3 Pp 2010. 